UDC [378.147: 004.77]:027.7

TURMYS O. V.

Department of Foreign Languages, Military Academy (Odessa, Ukraine), e-mail: olga.turmys@ gmail.com, ORCID 0000-0002-6728-6811

\title{
FEATURES OF THE EDUCATIONAL PROCESS IN THE INFORMATION AND TELECOMMUNICATIONS SOCIETY
}

Objective. The purpose of this paper is to analyze the impact of the development of information and communication technologies in society on the state of the educational process. In the study we applied such Methods as analysis of scientific materials, data processing and modelling of future educational process. Eventually we came to the Results that educational process is being in close correlation with the Web-technologies and telecommunications society, it is dynamically changing according to the current state of information environment. In Conclusions we summed up all the material and made prognosis for the members of educational process due to the positive and negative factors of effecting informatization on the educational process.

Keywords: information literacy; learning process; university library; millennials; information society

\section{Introduction}

University libraries around the world are required to conduct Information Literacy classes. As defined by the ACRL Framework for Information Literacy for Higher Education 2015 (https://otterbein.libguides.com/infolit/whatinfolit), Information literacy is a set of integrated skills that include reflexive disclosure of information, understanding of how information is produced and valued, and the use of information forcreating new knowledge and ethical participation of students in communities". That is, the educational process in university libraries is an established norm, and a competent librarian who professionally knows how to use information and communication technologies becomes a tutor, an adviser, a teacher.

Educational process is a structured system of organizational and didactic measures aimed at performing requirements of a definite educational level according to the state standards of higher education. Educational process is based on the principles of science, humanism, democracy, lifelong and degree education. Education is a complex human endeavour ultimately aimed at enhancing students' cognitive, civic, and social learning and development. Like medicine, law, or farming, education is a craft - a practical profession requiring specialized skill.At present, there is no particular need to substantiate the urgency of the problem of how to improve teacher training, since the issues of the quality of education are of concern to everyone: parents, students, practical teachers, researchers. In education, you can rely on the most general patterns, however, in addition to basic static conditions, the influence of those environmental factors that change dynamically in the learning process, the conditions of the information field, which can be called the context of education, acquires a colossal role.

\section{Methods}

Without pretending to globally cover the issue of context, let us dwell on what characterizes the educational process today, that is, we will focus on the conditions of the direct use of Information and Telecommunications technologies. The most important here are issues related to the role of the librarian-teacher/tutor in creating conditions for achieving quality education using the capabilities of modern technologies. 
It is impossible to deny the developmental and teaching possibilities of informatization of society: 3-D modelling, multifaceted research, analysis of large amounts of data (Data Mining), etc. However, the current situation with the active implementation of information technologies in the educational process for some teachers does not seem entirely appropriate. They believe that informatization has a negative character, since it is characterized by the formalization of didactic materials, excessive use of testing due to the simplicity of their organization through computers and the Internet, ease of obtaining information, etc.

At the same time, virtual reality and 3D modelling systems help to understand the laws of the Universe and the work of the circulatory system, the structure of chromosomes and the principle of engine operation. Computer simulation programs provide a visual environment for the study of biology, physics, chemistry. On the websites of modern libraries, you can explore in detail the ancient manuscripts and old prints, the works of art of great artists, and through the web-cameras of reserves and zoos, you can watch animals. In addition, new technologies provide unlimited possibilities for organizing joint disputes and conferences.

Nevertheless, there are many examples of the use of modern high-tech tools in an organic combination with traditional educational technologies.

Thus, regardless of the way the educational process is implemented, it is the personality of the teacher that plays the primary role in it. Because it is the teacher who intelligently selects the ways of using information technologies and the principles of their implementation in the educational process in the variety of modern technologies - creating a special educational environment that actualizes, integrates and develops the potential and capabilities of information technologies. The solution of such important tasks entirely depends on the teacher's preparedness - his professional competence and skills, including the use of modern high-tech gadgets and devices. Among the indispensable conditions in this regard is the policy of an educational institution aimed at supporting the innovative activities of their mentors.

At the same time, an expert on the integration of modern technologies into the educational process is, first of all, a teacher: it is he who decides whom, how and what to teach; what to develop and instill in students. However, no less important figures in the modern educational process are students, whose educational needs constantly stimulate the teacher to search for new ways and means of presenting material. And their practical skills in using the devices that characterize the modern telecommunication society allow them to become "teachers for teachers" to a certain extent.

\section{Results and Discussion}

In general, the peculiarities of the implementation of the educational process in educational institutions, including information literacy, have remained practically unchanged for several centuries. Students from year to year statically attended lessons, lectures, seminars, where, under the guidance of teachers, they acquired new knowledge. The tradition and even routine of the educational system (listening, repeating, remembering - sorting out at seminars, checking on tests and exams) does not deny the possibility of joint educational creativity and scientific research, active informal communication. At the same time, the teacher was perceived as a bearer of knowledge, cultural values, and certain moral norms. The specificity of education brought up respect for book knowledge and the corresponding perception of libraries. Indeed, what was available to the students? A regulated set of textbooks and anthologies, at best popular science and reference literature. For the teacher, this set was supplemented with special teaching aids (to a specific textbook) and periodicals with didactic collections and 
recommendations for teaching certain subjects. The teacher, as a rule, had a clear idea of what additional material was available to his students, and was ready to discuss any issues within his subject. The same thing happened in higher education: students most often had access only to the basic literature, which could be borrowed from the university library on the disciplines they study. Additional literature (rare or limited editions, scientific journals, etc.) was often purposefully supplied to individual students by the teachers themselves.

Over the past decades, the world has been massively computerized, children as part of it too. Foreign researchers classify those born in 1980-2000 as Net Generation, or Generation Millennium, or Millennials, or Digital Natives (Hargittai, 2010; Bennett, Maton \& Kervin, 2008; Buckingham \& Willett, 2006; Castells, 2001; Prensky, 2001, 2009). This generation has grown up actively using the Internet, mobile communications and various electronic gadgets, which are fundamentally changing the information mentality. The main characteristic feature of modern students, in comparison with previous generations, is the desire for instant (albeit superficial) satisfaction of information needs and the active use of all currently available devices for this (Castells, 2000; Kennedy, Judd, Churchward, Gray, \& Krause, 2008; Jones, Ramanau, Cross, \& Healing, 2010). Children and young people communicate in a new way, read, write, count, and perceive information. And all this is the result of informatization. This phenomenon, like any other, has its pros and cons.

Negative traits. The use of smartphones, tablets, etc., for educational purposes, would be welcome, but unfortunately, many schoolchildren and students sincerely consider superficial search and collection of information (on the issue under study) as a cognitive activity. We have to admit that the generation of the Web is characterized by satisfaction with superficial representations on any issue, they are satisfied with the first received counter-reference (at best from Wikipedia) to the required information, their natural curiosity is dulled, there is functional illiteracy in those cases when it is necessary to evaluate, compare, analyse independently any text material. And to the whole variety of electronic resources of great cultural importance (fulltext libraries, virtual museums, media lessons of foreign languages, etc.), students often prefer computer games, downloading and watching films and clips, spending time on social networks, etc.

As polls show, the majority of students use the Internet only as a communication technology, with the help of which they make up for the lack of communication or create an illusion of it.

Addiction to gadgets appears. In particular, from mobile phones. British researchers called the mobile phone "the next drug of the new generation." According to their data, every sixth inhabitant of the planet is under the influence of mobile addiction. Australian academician Diana James argues that a mobile phone causes psychological dependence in a person, which in its power exceeds a person's dependence on smoking! The researcher also believes that dependence on a mobile phone is higher than dependence on a computer, since you can leave the computer, and the mobile fits easily into your pocket. In the electronic dictionary of medical terms, the concept of "mobile addiction" is explained as follows: this is a person's condition in which the phone becomes an object of worship, the person unconsciously uses it without realizing his actions or cannot explain their reasons. And, although there is no independent mental disorder - mobile addiction, the survey carried out indicates rather high rates of adolescents' need for mobile phones.

Positive traits. Since technical progress is growing daily, it is impossible to prohibit or restrict the use of a mobile phone by students. Teachers cannot cope with this obvious dependence, in the conditions of permanent informatization of society, when mobile gadgets are 
an indispensable part of the life of a modern person. According to the author, it is necessary to make the use of this gadget conscious and constructive.

Nowadays, when, due to the coronavirus pandemic, the whole world is thinking more and more about the problem of introducing distance education, Intelligent tutoring systems computer-based educational systems that provide immediate and personalized instruction or feedback to learners, usually without intervention from a human teacher, acquire a huge value (Weller, 2007).

On the one hand, our schools, colleges, universities, academies are not yet sufficiently filled with computer equipment, on the other hand, at least $90 \%$ of students have the necessary information resource at hand (Bennett \& Maton, 2010). This means that we should not try to unsuccessfully resist their use, but try to introduce them into the educational process as teaching materials and manuals. Personal Experience - having tried to deal with the electronic version of the available printed edition of the textbook, students are already asking to conduct the next course of study using the textbooks in electronic form, regardless of their printed form.

It is generally known that those things that bring pleasure during learning are easier to remember. Emotions are conducive to learning. Emotions may be significant elements, which contribute to pedagogical success. The consequences of a positive affect can have a great impact on cognitive tasks, such as creative problem-solving and cognitive organization, facilitating them and increasing the intrinsic motivation for performing tasks. As far as a student is concerned, it has been shown that emotions have significance on the ability to learn new information or to solve problems. There are various studies that interpret particular affective states of a student, many pointing out that there is a strong connection between a student's emotion and a student's learning. Both neuroscience and psychology literature show the link between affect and performance on cognitive tasks. Lisetti (1999) considers that emotions have a significant influence on a wide range of cognitive tasks, such as decision-making, planning, adapting to new environments, and learning. Picard (1997) agrees, claiming that "emotions play an essential role in rational decision-making, perception, learning, and a variety of other cognitive functions."

\section{Conclusions}

For the success of the educational process, including information literacy, which is cared for by university libraries around the world, nowadays it is necessaryfor teachers to be able to use in practice modern high-tech devices in their professional activities, as well as to use them with a creative approach within the formulation and solution of educational problems, for a beneficial effect on the development of students. The teacher must create a special context that will allow you to move away from simplified actions to the real embodiment of the wildest fantasies for the sake of high-quality teaching.

It is necessary for a teacher to be ready for creative experiments, for mastering practical IT-competencies and understanding the essence of the technologies corresponding to them, for accepting and managing a given context of the educational process within its dynamic development. Thus, within the framework of the educational process, it seems appropriate to use modern technologies for at least the following purposes:

- presentation and explanation of the main ideas of the subject and intrasubject connections using illustrative examples and models;

- encouraging students to seek answers to the "why" and "how" questions;

- adaptation and addition of the content of textbooks with demonstration materials, variable multilevel tasks; 
- collection, generalization and analysis of data on the use of various educational technologies and teaching methods in the process of experimental work;

- monitoring of educational achievements and support of individual educational routes.

\section{REFERENCES}

Bennett, S., \& Maton, K. (2010). Beyond the 'digital natives' debate: Towards a more nuanced understanding of students' technology experiences. Journal of Computer Assisted Learning, 26(5), 321-331. doi: https://doi.org/10.1111/j.1365-2729.2010.00360.x (in English)

Bennett, S., Maton, K., \& Kervin, L. (2008). The 'digital natives' debate: A critical review of the evidence. British Journal of Educational Technology, 39(5), 775-786. doi: https://doi.org/10.1111/j.1467-8535.2007.00793.x (in English)

Buckingham, D. \& Willett, R. (Eds.). (2006). Digital Generations: Children,Young People and New Media. Mahwah, NJ: Erlbaum. doi: https://doi.org/10.4324/9780203810668 (in English)

Castells, M. (2000). The rise of the network society (2nd ed.). Oxford, UK: Blackwell Publishers. (in English)

Castells, M. (2001). The Internet galaxy: Reflections on the internet, business, and society. Oxford, UK: Oxford University Press. (in English)

Hargittai, E. (2010). Digital Na(t)ives? Variation in Internet Skills and Uses among Members of the "Net Generation". Sociological Inquiry, 80(1), 92-113. doi: https://doi.org/10.1111/j.1475682X.2009.00317.x (in English)

Jones, C., Ramanau, R., Cross, S., \& Healing, G. (2010). Net generation or digital natives: Is there a distinct new generation entering university? Computers and Education, 24(3), 722-732. doi: https://doi.org/10.1016/j.compedu.2009.09.022 (in English)

Kennedy, G., Judd, T.S., Churchward, A., Gray, K., \& Krause, K. (2008). First year students' experiences with technology: Are they really digital natives? 'Questioning the net generation: A collaborative project in Australian higher education'. Australasian Journal of Educational Technology, 24(1), 108-122. Retrieved from http://www.ascilite.org.au/ajet/ajet24/kennedy.html (in English)

Lisetti, C. (1999). A User-Model of Cognition-Emotion. Proceedings of the UserModelling First Workshop on Attitude, Personality, and Emotions in User-Adapted Interaction, 25-35. (in English)

Picard, R. W. (1997). Affective Computing. Cambridge, MA: M.I.T. Press. (in English)

Prensky, M. (2001). Digital natives, digital immigrants. On the Horizon, 9(5), 1-6. doi: https://doi.org/10.1108/10748120110424816 (in English)

Prensky, M. (2009). H. sapiens digital: From digital immigrants and digital natives to digital wisdom. Innovate, 5(3). Retrieved from https://nsuworks.nova.edu/cgi/viewcontent.cgi?article=1020\&context=innovate (in English)

Weller, M. (2007). Virtual Learning Environments: Using choosing and developing your VLE. Oxford, UK: Routledge. (in English) 
THE CONTRIBUTION OF THEORY AND RESEARCH TO THE TRANSFORMATION OF LIBRARIES

ТУРМИС О. В.

Кафедра іноземних мов, Військова академія (Одеса, Україна), e-mail: olga.turmys@ gmail.com, ORCID 0000-0002-6728-6811

\section{ОСОБЛИВОСТІ ОСВІТНЬОГО ПРОЦЕСУ В ІНФОРМАЦІЙНО- ТЕЛЕКОМУНІКАЦІЙНОМУ СУСПІЛЬСТВІ}

Мета. Метою даної роботи є аналіз впливу розвитку інформаційно-комунікаційних технологій у суспільстві на стан навчального процесу. Методика. Під час дослідження ми застосували такі методи, як аналіз наукових матеріалів, обробку даних та моделювання майбутнього навчального процесу. Результати. Проаналізувавши ситуацію, ми дійшли до того, що навчальний процес знаходиться у тісному взаємозв'язку 3 Веб-технологіями та телекомунікаційним суспільством, він динамічне змінюється відповідно до сучасного стану інформаційного середовища. Висновки. Ми узагальнили матеріали дослідження та, відповідно до наявних позитивних та негативних факторів, що впливають на інформатизацію навчального процесу, зробили прогноз майбутніх перспектив для учасників навчального процесу.

Ключові слова: інформаційна грамотність; навчальний процес; університетська бібліотека; міленіали; інформаційне суспільство 